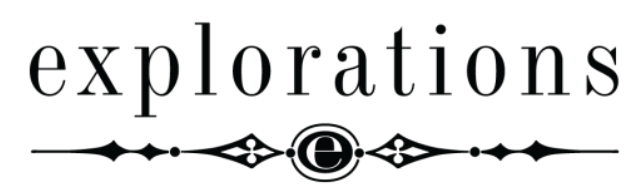

Explorations: A Journal of Language and Literature

\title{
"For not only do we lose everything if we lose our land. We also become nothing." 1 The representation of land in contemporary New Zealand literature
}

\author{
Ewa Kroplewska (University of Gdańsk) \\ DOI: $10.25167 / \mathrm{EXP} 13.17 .5 .5$
}

\begin{abstract}
Land has always played a crucial role in New Zealand indigenous people's identity. After years of European suppression it has evolved into one of the themes of contemporary New Zealand literature. In their novels, native writers such as Keri Hulme, Witi Ihimaera and Patricia Grace use land not only as an element of the setting. In these representations, land functions as a place of tradition and belonging, a reminder of the past, but also as a target of colonial abuse. Each of the writers presents a new perspective on the role of land, yet, their perceptions are in many aspects coincidental.
\end{abstract}

Key words: Post-colonialism, land, New Zealand, Ihimaera, Hulme, Grace

\section{INTRODUCTION}

After years of suppression and the inability to speak with their own voice, the indigenous inhabitants of New Zealand were finally blessed with writers who attracted public attention to the Maori issue. The so-called "Maori Renaissance", a rebirth of Maori artistic activity, is dated to have begun in the early 1970s (Williams 2006, 208). The Maori Renaissance writers, among whom one can find Witi Ihimaera and Patricia Grace, have since then been articulating the problems of Maori community in the postcolonial times. They have addressed the issues of an ongoing exploitation, land loss and inferior treatment, but they have also shed light on the rich cultural heritage of the Maori people: their mythology, history and traditions.

Soon after the first colonizers arrived in New Zealand, they started to purchase the land from Maori people. According to the Encyclopedia of New Zealand,

\footnotetext{
${ }^{1}$ The quotation comes from the novel The Matriarch by Witi Ihimaera $(1986,236)$.
}

Explorations: A Journal of Language and Literature, 5 (2017), pp. 47-60 
Early settlers such as missionaries, whalers and traders were hungry for land. Often a Māori chief would allow Europeans to settle on a piece of land in exchange for goods, but did not imagine that this meant granting them absolute ownership. Instead Māori saw it as a transfer of particular rights, while their own rights remained untouched. Māori were keen to attract Europeans for trade, and land transactions were common. ${ }^{2}$

Land is crucial in the understanding of Maori identity and the importance of its preservation becomes a major theme in the works of contemporary Maori writers. As Swarnalatha Rangarajan (2016) asserts in "Women Writing Nature in the Global South: New Forest Texts from Fractured Indian Forests", published in Handbook of Ecocriticism and Cultural Ecology,

[..] Maori writers like Patricia Grace and Keri Hulme's narratives construct the landscape as a vital actor whose health is essential to the flourishing of humans and culture. These writers approach ecological restoration in holistic ways and consider the re-narrativising of traditional ecological knowledge as essential for building a sustainable relationship between lands and humans. (440)

For Maori people, the land is their inalienable right, it is part of their heritage. Land, in the Maori culture, functions not only as a sacred site of tradition, giving the Maori a sense of belonging, but also as a place of remembrance of the past and the ancestors. Yet, due to the increasing influence of the colonizers it has also become a place of colonial exploitation.

This article is aimed at analyzing the meaning of land in contemporary New Zealand literary representations, focusing on five novels: The Bone People by Keri Hulme, Potiki and Baby No-Eyes by Patricia Grace, and also on The Whale Rider and The Matriarch by Witi Ihimaera.

\section{LAND AS A SITE OF THE PAST, TRADITION AND BELONGING}

The Maori people have always cultivated a special, almost organic relationship with their land. In "The Fiction of Patricia Grace", John Beston ascribes this phenomenon to their little knowledge of the world outside their tribes:

The Maori feeling of closeness to the land [...] can amount to near identification. We should remember that the Maori, after their initial settlement in New Zealand, were not great travellers or geographers (there is no evidence, for instance, that they ever visited nearby Australia before European settlement there); they saw the world in very local and personal terms. $(1984,47)$

The lives of Maori people have always depended on the land cultivation. The fruits of their own ground have remained the basic provisions, so they have learnt to appreciate the soil and its produce, treating it with due respect. The Whale Rider by Witi Ihimaera contains a description of one of the ancestors' arrival to New Zealand, in which the

\footnotetext{
2 The excerpt comes from the online edition of the Te Ara Encyclopedia of New Zealand http://www.teara.govt.nz/en/land-ownership/page-1
} 
people's fertility is marked as equally important to the land's fruitfulness. At the same time, the excerpt underlines that the future of the man is closely related to the land:

It was in this land that Paikea's destiny lay. He married the daughter of Te Whironui, and they were fruitful and had many sons and grandsons. And the people lived on the lands around his home at Ranginui, cultivating their sweet potato and vegetable gardens in peace and holding fast to the heritage of their ancestors. (Ihimaera 2005, 23-24)

In Patricia Grace's novel Potiki one may read how proud the father of the family, Hemi, is because he cultivates his own piece of land. This does not entail that people should regress only to the land cultivation. Rather, the land cultivation should be seen as a possibility of progress 95). According to Claudia Duppé (2010),

[f]rom a more general ecological standpoint, one might say that Māori philosophy still forms one of the most radical positions against the pursuit of progress and technological advancements that characterizes Western civilization. In fact, Māori agricultural practices follow the principles of bio-dynamic farming $[\ldots]$, which the organic food movement considers the most sensible step into a sustainable future. $(128-129)$

Hemi appreciates the work he does as it serves his family and does not contribute to some landlord's wealth:

But he didn't want to see these young ones breaking their backs, even though it was for... survival, getting enough food and a bit of money to keep them all. Then again if you looked at the other side of it, at least they could say they'd seen the fruits of their own work, and that the fruit they got was their own. Different from working for a boss where you stayed poor anyway, stayed poor and made someone else rich. (Grace 1986, 146-147)

As Paola Della Valle (2010) notices in From Silence to Voice: The Rise of Maori Literature: "[...] in Maori culture land does not belong to the people, rather people belong to the land" (7). An important marker of people's close ties with the land is the ritual performed after the birth of a baby. Ngahuia Te Awekotuku (1996) explains this practice in "Maori: People and Culture":

Papatuanuku is the Earth Mother, combining all elements of the planet; her immediate form is whenua, the land. Continuing the organic metaphor, whenua is also the Maori word for the placenta, which is promptly buried with simple ritual after birth. This practice is still observed today, even is cities, thus the word itself reflects the relationship between people and the land [...]. (33)

According to Dianne Wepa and Jean Te Huia (2006), "[t]he philosophy here is that through this process Papatuanuku will continue to feed and sustain the life of all humanity" (26). They also claim that the practice itself differs according to the specific tribe (26). A literary example of this process can be found both in the aforementioned The 
Whale Rider. When baby Kahu is born, her mother dies. The family becomes responsible for burying the girl's afterbirth and initiating her relationship with the land:

Rehua was still in intensive care and Porourangi had to stay with her, but apparently she wanted Kahu's afterbirth, including the birth cord, to be put in the earth on the marae in our village. An auntie of ours would bring the birth cord back to Gisborne on the plane the next day. (Ihimaera 2005, 16)

Baby No-Eyes also offers a description of Tawera's rite of passage after his birth (Visser 2010, 284). His placenta is buried under a sapling tree brought by Gran Kura from her family home. This allows Tawera to become one of the tangata whenua, the 'people of the land' (Te Awekotuku 1996, 33). Tawera describes the situation himself: "Gran gave me back to Mum and wrapped my placenta ready to put out in the garden under a little tree that she'd brought all the way from home with her" (Grace 1998, 19).

Maori identity is directly connected to the land they belong to. Janet Wilson (2008) in "Suffering and Survival: Body and Voice in Recent Maori Writing" claims that the aim of the contemporary literature is, among others, "to affirm the interconnectedness between members of the community and the common identity between the individual, whanau and the land. This is central to Maori identity as tangata whenua (people of the land)" (267). In Potiki, Roimata describes Hemi in such words: "My husband, as rooted to the land as a tree is" (Grace 1986, 175). Further on, one may read: "It's land and people that are a person's self, and to give to the land and to give to the people is the best taonga of all" (176).

Contemporary Maori literature foregrounds the importance of the wharenui and the marae - structural elements of the Maori settlements. In "The Trauma of Goodness in Patricia Grace's Fiction", Irene Visser (2012) offers to view the marae (the ground in front of the Maori meeting house) as a symbol of identity (306). According to Ranginui Walker (1992), "[t]he marae is an institution where a Maori has turangawaewae, standing, in relation to the dominant culture of the Pākehā" (26). In the article "On Reading Grace's Potiki", Eva Rask Knudsen (2011) confirms this point of view: "In Māori culture, the wharenui is not simply a venue, it embodies the spirit of the land and people, it is a turangawhaewhae (a place to stand)" (7). She extends this idea by giving example of the wharenui and the marae as presented in Potiki:

In Māori culture, the wharenui (meeting house) situated on the marae (ceremonial ground) is the most significant site of Maoritanga as it is $-[\ldots]$ a prominent site for dialogue and cultural exchange. Since the Māori Renaissance, the wharenui has been a central trope in Maori literature, such as in Witi Ihimaera's The Matriarch (1986) and in Keri Hulme's The Bone People (1985) and prominently so in Grace's collective works $[\ldots]$ in which the wharenui is either inaugurated ceremonially, featured as the animated recording agency of the community life, or sanctioned as the final site of communal reconciliation. [...] In Potiki, however, the wharenui is more than a trope: it is a structural design, a piece of literary architecture in which all voices hosting within the house come together to address the visiting reader in a way that translates Māori epistemology from voice to print. (3) 
Potiki indeed offers a peculiar description of the meetinghouse: "There was in the meeting-house a warmth. It was the warmth that wood has, but it was also the warmth of people gathered. It was the warmth of past gatherings, and of people that had come and gone, and who gathered now in the memory" (Grace 1986, 88). This excerpt underlines the symbolism of the meeting-house as a place where the past and the present overlap, where tradition is renewed and remembered. Suzanne Romaine (2004) goes even further in "Contested Visions of History in Aotearoa New Zealand Literature: Witi Ihimaera's The Matriarch", claiming that "[t]he meetinghouse itself is the body of an ancestor, signifying the continuing presence of the ancestors in community life" (52). In "Maori Literature: Protest and Affirmation", Karen P. Sinclair (1992) also addresses the importance of the meeting house:

Maori spirituality is perhaps nowhere more evident than in their attachment to the land, which has mystical, not material, value. It is the land that encloses and nurtures the family, a unit that supersedes all other allegiances. The meetinghouse is, as both Grace and Ihimaera remind the reader, shaped like a human body. To enter is to be embraced by the totality of ancestors that have preceded the current community. (294)

The meetinghouse in The Matriarch called Rongopai also proves to be an important reminder for the Maori people - both of the past and of the present. Sinclair (1992) explains that "[p]eople are tied to the land and to their ancestors through a heritage that is represented as simultaneously political and spiritual" (286). Rongopai is such a heritage, a symbol of strength (Romaine 2004, 52): "[The Maori people] had faith in Rongopai as a symbol of their Maoritanga at a time when this was being slowly snuffed out by the ways of the Pakeha. They dreamt dreams of pride in self and in the iwi. Rongopai was their political statement" (Ihimaera 1986, 194).

In The Bone People by Keri Hulme (1985) one reads about another important example of a meeting house. The heroine of the novel decides to rebuild the Maori hall in an attempt to rejoin her community. She offers a commentary on this act: "We have not just a hall, but a marae again. The fire's been relit, and I sink gracefully back into oblivion having lit it" (432). Thanks to this action, the building becomes a living heart of the community.

The urupa is yet another piece of land important to the Maori people. The burial ground is a place of remembrance about the past. By visiting the site the Maori children learn about their ancestors: "Once inside [...] [t]hey would read the stones and discuss the dead, retelling the stories they'd heard and told over and over again" (Grace 1986, 121). The whole chapter of the novel is devoted to the description of the burial site and underlining the care with which it is treated (121-126).

The unity with the land proves to be a healing medium. As Stephen D. Fox (2004) claims in "Barbara Kingsolver and Keri Hulme: Disability, Family, and Culture," "[e]ach character must reunite with the land before he or she can merge again with family and society" (277). That is the reason why characters in the novels decide to come back and reunite with their ancestors' land.

One of the instances of such return to the land may be found in Potiki, when the father of the Tamihana family - Hemi, loses his job, he remembers about the education provided by his grandfather - his "apprenticeship" (Grace 1986, 59) on the land, learning about 
growing, seasons and weather. He is glad that his family is located in the land of his ancestors and that they have the ground to harvest:

He's always known that one day he would return to the land, and that the land would support them all again. And they still had their land, that was something to feel good about. [...] Now, at least, the family was still here, on the ancestral land. They still had their urupa and their wharenui, and there was still clean water out front. [...] And the people were looking to their land again. They knew that they belonged to the land, had known all along that there had to be a foothold otherwise you were dust blowing here and there and anywhere - you were lost, gone. (60-61)

In The Bone People, one of the main characters, Joe, decides to retaliate for all his previous sins: the alcohol abuse, the beating and maltreatment of his son and the conflicting relationship with Kerewin. In order to fulfil this, he sets on a journey to find a wise man (the kaumatua), who can help him restore peace within himself. In "The (Handi)Craft of Fiction: Raranga and Whatu in the bone people" Rehab Hosny Abdelghany (2013) explains the connection between the human being and the land as shown in the novel, underlining the importance of the land's impeccable state. He claims that " $[\mathrm{t}]$ he kaumatua's virgin land is stressed as the spatial link with the ethereal essence of the ancestral heritage" (197). In a magical realistic scene, the kaumatua expounds to Joe the importance of the land and the need to care for it, referring to the story of Mauri, the spirit of the land brought by the old settlers. Joe is told to keep guard of the land and to protect its spirit (Hulme 1985, 364-371). As Eva Rask Knudsen (2004) explains in The Circle and the Spiral, "by experiencing the spirituality of place Joe realizes that sacred matters die if they are reduced to artefacts and placed in the museum, just as the Kaumatua realizes that other people must bring the spirituality of his solitary place into a community context" as "mauri is alive in both land and people" (179). Joe comes to understand that the land is where his Maoriness lays and the kaumatua learns that it is not the ties to the specific land, but to land as such, that hold the key to renewing the relationship between the people and environment. As Knudsen (2004) offers to view it, "the novel's specific sense of place could not have been fully established without the Kaumatua episode, because it explored the spiritual and sacred meaning of geographical place" (181).

\section{CORRUPTION, EXPLOITATION AND DISPOSSESSION OF THE LAND}

The colonisation of New Zealand brought about a lot of changes to the Maori lifestyle, among which there were changes to the property ownership. The land was bought by the settlers and served utilitarian needs. As Chris Prentice (2009) writes in "From Visibility to Visuality: Patricia Grace's Baby No Eyes and the Cultural Politics of Decolonization", "Land and bodies figure as sites of colonial expropriation, exploitation, and violence" (322). In their novels, the Maori writers voice the issues related to the appropriation and/or purchase of the land, its consequences and the future implications.

In general, the land becomes divided into the realm of the countryside - old, rural area where tradition is still cherished - and the city - area of corruption. This dichotomy is 
visible in a number of novels. In "The Fiction of Patricia Grace", John B. Beston (1984) comments upon the negative effect of urbanisation:

One change that came with the Pakeha was the rise of an urban, wage-earning society that functions by buying and selling; the Maori drift to the city to find employment was in consequence inevitable, and their age-old ties to their land were severed and the ties to their family weakened. (46)

Keri Hulme (1981) also offers a negative opinion on the urbanisation of New Zealand: "Once a rural and tribal people, Maoris have now become urban and divided into very small family groups. [...] In the cities, you are cut off from the life of the land, the sea, your family marae, from your ancestral roots" (293).

Sinclair (1992) confirms this view, claiming that the New Zealand literature is abundant in examples of this phenomenon:

Grace's and Ihimaera's move to prove the Maori urban experience was not simply a change in scene; for each of them the move from rural to urban environment, from home to hostile territory, meant the discussion of domestic rupture, permanent fault lines that splinter kin groups, violent confrontations between Maori and between Maori and Pakeha. In Potiki, for instance, Grace describes Pakeha appropriation of Maori land, while in The Matriarch Ihimaera explores schisms in the community that compound the complex social relations - marred by the violent battles between Maori and Pakeha - in the nineteenth century. In these types of portrayals, the writers reflect both social and literary trends in New Zealand: Maori have become far more assertive, more positive in their statements of their identity, more willing to be intensely critical of Pakeha presumptions of cultural supremacy. (287)

As Allan Hanson (1989) aptly observes in "The Making of the Maori: Culture Invention and Its Logic", "Pakeha culture is out of step with nature - it pollutes the environment and lacks a close tie with the land" (894). This contrast between Maori and Pakeha is visible in Potiki, where one may read about the negative changes that are brought about by colonisation. First of all, it offers the story of Te Ope people - a community fighting to reclaim the rights to the land of which they were dispossessed during the First World War. According to Knudsen (2004), it "is recaptured in Grace's Māori community, and it functions as a model of resistance which informs the Tamihana whanau (extended family) and its present fight to resist Pakeha land developers who want to build a resort in the vicinity" (189). Indeed, a building company wants to buy the land to provide a road for their new investment. In the conversation between the developers and the Maori community, Mr Dolman proposes to remove the meeting house and other structural elements to a different piece of land. He views the land in terms of its material value. He refers to the separate pieces of land as "Block JI36, the attached blocks where the houses are, and J480 to 489 at the back of the houses" (Grace 1986, 89), whereas to the Maori it is "inalienable ancestral land" (Knudsen 2004, 190), "[their] meeting place, [their] identity, [their] security" (Grace 1986, 93). Karim Abuawad (2012) in "Patricia Grace's Potiki: A Case Study for the Adaptability of Postcolonial Theory to Indigenous Literature" attempts to explain the reasons for the Pakeha behaviour: 
The attempt at appropriating land in Potiki, first by financial enticement and later by intimidation, is predicates on the old colonial idea that land can be acquired through labor; that land belongs only to those who can make it bloom. The land's value as such is dwarfed in comparison with the value of the work that transforms it. Since the people in possession of land are unwilling or incapable of bringing about such transformation, this kind of reasoning goes, the right to the land must be handed over to those who can turn deserts into oases. (88)

As Mr Dolman claims, the Maori people do not see the "full potential" of the land, such as "[a] million dollar view" (Grace 1986, 92), so he feels entitled to obtain the land in any way possible. When the people refuse to sell the land, their ancestral ground is destroyed by the builders, who flood the burial site, set fire to the settlement and bomb the sacred house (Knudsen 2004, 189).

Development acquires negative connotations; machines are brought not to improve the land, but to ruin it: "So we all went back to our beds and listened to the machines and to the cracking and falling of timber, and to a string of detonations, some near and some far away. The machines seemed to come nearer, and it was almost full light. Then the engines stopped" (Grace 1986, 166). Yet, Beston (1984) claims that Grace does not voice a direct accusation at the Pakeha people:

Although a number of the changes that have attended the Pakeha occupation and development of New Zealand have diminished the fullness of Maori life, Grace does not on that account point an accusing finger at the Pakeha. She is conscious of the damage to the Maori way of life and sense of identity, but restricts herself to recording the changes and their effects. (46)

In Graham Huggan and Helen Tiffin's (2015) book titled Postcolonial Ecocriticism: Literature, Animals, Environment there is a chapter by the name of "Development", in which one reads:

Patricia Grace's 1986 novel Potiki has been read as a poetic meditation on the struggle between 'nativist' and 'developmentalist' understandings of land, the former being associated with the view of land as unchallengeable spiritual obligation and the latter with land as exchangeable material resource. (71)

In their view, by means of dispossessing Maori people of their land, the Pakeha also deprive them of their roots, as narratives, just like trees, are embedded both in the land and in each other, underlining the interconnectedness of stories, people and land: "[t]his ecology is more than just a network; rather, as the term 'ecology' implies, it is a sphere of co-dependent interaction that connects people to the other ecological beings, both animate and not, that share their phenomenal life-world" (Huggan and Tiffin 72).

One of the subplots in The Matriarch is also the fight to regain the rights to the ancestral land. It shows the historical overview of the land rights acquisition. At one point the eponymous matriarch tells her grandson of the bonds that tie Maori with their land and how they have come to be broken: 
'We are the tangata whenua, the people of the land. How we came to be here, nobody knows. Perhaps we have always been here - Ancients descended from the Time of Gods.' [...] 'E mokopuna, we ruled here for over a thousand years. This was our land. This was out life. It is your life and land now.' [...] 'Then came the Pakeha.' (Ihimaera 1986, 4-6)

In this excerpt one can see the deep sorrow for the loss of the land. What is underlined is the Pakeha negative impact on the fate of the Maori people. The Matriarch retells the story of the land wars in order for her grandson to understand the reasons of the precarious conditions of the Maori people. As Romaine (2004) claims, "The Matriarch probes from a Māori perspective the causes of Māori alienation and dispossession from their land, in the belief that past historical injustices must be acknowledged before they can be resolved" (32).

Yet, The Matriarch offers a further and more politically involved commentary upon the dispossession of land, blaming the Pakeha people for the humiliation of the Maori people. The overtone of the excerpt is bitter regret about the past:

The land, always the land. The Maori people possessed it, but the white man has always lusted for it. From the very beginning of organised Pakeha colonisation in 1840, many Maori tribes had opposed the sale of land. There were rumours that the government intended to confiscate all Maori land. Let's admit it: the Land Wars began when the Maori lost the upper hand in Aotearoa, and particularly around 1858 when the census revealed that in a small space of thirty years there were already more white settlers than indigenous dwellers. The views of Maori and Pakeha about the future of the country were absolutely incompatible. The government attempted to buy more and more land, urgently needed by the Pakeha settlers; the Maori people considered these attempts to be against their express wish to retain the land. So the long wearying war began, which the Maori people appropriately called "the white man's quarrel. [...] But the war was lost, the war over the body of Papatuanuku, and the Maori throughout the land tasted bitterness. He had to endure confiscation and to become no more than a black slave in the new antipodean white South. Altogether 3,215,172 acres of Maori land were confiscated in the Waikato, Taranaki and the Bay of Plenty to pay for Maori insurgency. (Ihimaera 1986, 238-239)

It is also the Pakeha law regarding the land that was imposed upon the Maori people. In Baby No-Eyes one reads about the introduction of new regulations and how the Maori people had to adjust to them in order not to lose their land:

The government didn't like land to be in the hands of whole groups of people. They didn't like it to be in the hands of grandchildren's children - children who hadn't yet been born. It was difficult for them steal from so many owners. So they set up a Land Court to make it easier for themselves. This court drew up titles to pieces of land, making three or four men the new owners. This is how Tumanako and two of his relatives became owners, in the coat-owning way, of land they really knew was for everyone - land from river to river, from the coast to the hills and beyond. If they hadn't accepted these titles the land would have been taken away. (Grace 1998, 115) 
The Maori people accepted the fate, and, as one reads in Baby No-Eyes, even helped the settlers build new roads. But the Pakeha's desire for land has grown intensely (Grace 1998, 112-113). Throughout the novel, the Maori people fight a futile battle to regain the rights to the mountain, which shows that for them land has spiritual, not material meaning: "Surely, with the climate as it was these days they could bring about the return of one measly piece of land that no one else had any use for, but which meant a lot to the old man and to themselves" (49). Yet, the administration is intransigent, so is any kind of procedural institution, as in Baby No-Eyes the "extractive colonial practices such as land dispossession and new, 'biocolonial' activities regarding the mining of the human body" (Barker 2013, 141) are treated as equally grave problems.

Through the dispossession of land the colonisers and neocolonisers (in case, for instance, of Baby No-Eyes) interfere with the cultural heritage of the people. Jen Crawford (2005) in "Spaze: Void States and the Mother-Child Relationship" explains that Grace's and Ihimaera's novels are concerned with "the survival of Maori people and culture within the colonised world. The struggles for land rights and for the maintenance of cultural heritage are constantly foregrounded. These movements respond to conditions of cultural and material depletion" (272).

Yet, it is not only the loss of the land and the fate of the community that Maori people are concerned about. They are worried about the destruction of the ecosystem by the tourists (Murphy 2015, 95), being an entirely new phenomenon. They aim at protecting the land from negative physical factors. Their ecological ethics is clear: Maori people are fighting against the use of land against its traditional purpose:

The hills and the sea did not belong to us but we wished to see them kept clean and free. We could only be objectors along with others who liked to swim and camp and fish, and who did not want the sea or land changed. We, like them, did not want the company to make zoos and circuses in the sea, or to put noise and pollution there, or to line the shore with palaces and castles, and souvenir shops, or to have restaurants rotating above the sea, lit up at night like star crafts landing their invaders on the shore. (Grace 1986, 98, my emphasis)

Maori people wish to keep the land unchanged, yet, they do not wish for the complete absence of Pakeha people. The clear division between what the Pakeha peoples destructive force and the Maori people's sense of belonging to the land is hence blurred.

With the cultural depletion comes the issue of Maori spirituality. The conflict over the land was supposed to break Maori resistance, to weaken their beliefs, to force them to forget about their heritage. As one reads in The Matriarch, "It wasn't good enough just to take away our lands. Oh no, the Pakeha had to take away our souls too! Not only did we have to give up our physical world; we had to give up our spiritual world as well" (Ihimaera 1986, 71).

Still, the abovementioned novels offer hope for the future renewal of the land and its people. In The Bone People the conversation between the kaumatua and Joe underlines all the damage done to the land. The kaumatua first voices his fears about the future of the land. "Maybe we have gone too far down other paths for the old alliance to be reformed, and this will remain a land where the spirit has withdrawn. Where the spirit is still with the land, but no longer active. No longer loving the land'. He laughs harshly. 'I 
can't imagine it loving the mess the Pakeha have made, can you?"'. The pessimistic thoughts are confirmed by Joe, who enumerates all the wrongdoings of the Pakeha: "Joe thought of the forests burned and cut down; the gouges and scars that dams and roadworks and development schemes had made; the peculiar barren paddocks where alien animals, one kind of crop, grazed imported grasses; the erosion, the overfertilisation, the pollution...." Yet, the kaumatua claims there is still possibility of redemption: "Eternity is a long time,' says the kaumatua comfortably. 'Everything changes, even that which supposes itself to be unalterable. All we can do is look after the precious matters which are our heritage, and wait, and hope"" (Hulme 1985, 371).

Potiki, too, is viewed to have a positive overtone. As Paloma Fresno Calleja (2005) asserts in “"Meaningful Wor(l)ds': Patricia Grace's Bicultural Fiction”,

The opposition between the coastal community and the developers causes the destruction of the community's marae, the flooding of the village, and the death of Toko, the youngest child or potiki, in what seems as an evident victory over the community. However, Grace's characters are never presented as victims, but rather as powerful individuals who stand up and raise their voices in efficient narrations and dynamic linguistic exchanges. (37)

The story offers an optimistic conclusion: "The hills will be scarred for some time, and the beach front spoiled. But the scars will heal as growth returns, because the forest is there always, coiled in the body of the land. And the shores, the meeting places of the land and sea, if left will become clean again" (Grace 1986, 169). In his review of Potiki, Beston (1986), too, argues that the novel "asserts the ultimate establishment, after suffering and endurance, of peace and renewal" (501).

No clear solutions are given, though. None of the novel provides the readers with a recipe for a possibility of the reunion with the land in the times of ongoing technological development. Potiki offers to view farming as a sustainable form of the use of land for the future, yet, it does not suggest any actions.

\section{CONCLUSiOnS}

To conclude, all the novels mentioned in the article (Witi Ihimaera's The Whale Rider and The Matriarch, Patricia Grace's Potiki and Baby No-Eyes, and also Keri Hulme's The Bone People) provide the readers with an overview of the condition of the land in contemporary New Zealand. They draw attention to the importance of the land to the Maori people, by underlining the references to the past, history and tradition. The ties between people and their land are presented as one of the constituting values of the Maori culture. At the same time, the aforementioned novels provide numerous examples of how the arrival of the Europeans changed the landscape of Aotearoa. They present many instances of land dispossession, the corruption of the rural life and general damage done to the Maori culture. They do not consider Pakeha solely as destructors, though. The novels provide uplifting endings: there is still hope for the Maori and their land. According to the Maori writers, it is high time to renew the relationship between people and the surrounding environment and it is only through renewed kinship that the Maori 
people can regain their integrity. Still, there are no ready-made solutions presented in the novels.

\section{REFERENCES}

Abdelghany, Rehab Hosny. 2013. "The (Handi)Craft of Fiction: Raranga and Whatu in the bone people." Journal of New Zealand Literature: JNZL 31(2): 183-207. Accessed June 14, 2017. http://www.jstor.org/stable/23724112.

Abuawad, Karim. 2012. "Patricia Grace's Potiki: A Case Study for the Adaptability of Postcolonial Theory to Indigenous Literature." The Word Hoard 1(1): 10. Accessed September 7, 2015. http://ir.lib.uwo.ca/cgi/viewcontent.cgi?article=1009\&context=wordhoard

Barker, Clare. 2013. “"The Ancestors Within.' Genetics, Biocolonialism, and Medical Ethics in Patricia Grace's Baby No-Eyes.” Journal of Literary \& Cultural Disability Studies 7(2): 141-158. Accessed June 15, 2017. https://muse.jhu.edu/article/518196.

Beston, John B. 1984. "The Fiction of Patricia Grace." ARIEL: A Review of International English Literature 15(2): 41-53. Accessed 15 June, 2017. https://journalhosting.ucalgary.ca/index.php/ariel/article/viewFile/32747/26799.

Beston, John B. 1986. "Potiki, Patricia Grace." Review of Potiki, by Patricia Grace. Landfall 40(4): 501-502.

Crawford, Jen. 2005. "Spaze: Void States and the Mother-Child Relationship in The Matriarch, The Dream Swimmer, Cousins and Baby No-Eyes." Kunapipi 27(2): 268275. Accessed October 25, 2016. http://ro.uow.edu.au/kunapipi/vol27/iss2/1.

Della Valle, Paola. 2010. From Silence to Voice: The Rise of Maori Literature. Auckland: Libro International.

Duppé, Claudia. 2010. "Asset or Home? Ecopolitical Ethics in Patricia Grace's Potiki." In Local Natures, Global Responsibilities: Ecocritical Perspectives on the New English Literature, edited by Laurenz Volkmann et al, 121-135. New York: Rodopi.

Fox, Stephen D. 2004. "Barbara Kingsolver and Keri Hulme: Disability, Family, and Culture." Critique: Studies in Contemporary Fiction 45(4): 405-420. Accessed June 14, 2017. http://dx.doi.org/10.3200/CRIT.45.4.405-420.

Fresno Calleja, Paloma. 2005. “Meaningful Wor(1)ds': Patricia Grace's Bicultural Fiction." In On the Road to Baghdad or Traveling Biculturalism: Theorizing a Bicultural Approach to Contemporary World Fiction, edited by Gönül Pultar, 27-45. Washington: New Academia Publishing.

Grace, Patricia. 1986. Potiki. Auckland: Penguin.

Grace, Patricia. 1998. Baby No-Eyes. Auckland: Penguin.

Hanson, Allan. 1989. "The Making of the Maori: Culture Invention and Its Logic." American Anthropologist 91(4): 890-902. Accessed June 15, 2017. https://www.jstor.org/stable/681587.

Huggan, Graham, and Helen Tiffin. 2015. Postcolonial Ecocriticism: Literature, Animals, Environment. London: Routledge.

Hulme, Keri. 1981. "Mauri: An Introduction to Bicultural Poetry in New Zealand." In Only Connect: Literary Perspectives East and West, edited by Guy Amirthanayagam 
and S. C. Harrex, 290-310. Adelaide \& Honolulu: Centre for Research in the New Literatures in English \& East-West Centre.

Hulme, Keri. 1985. The Bone People. London: Picador.

Ihimaera, Witi. 1986. The Matriarch. Auckland: Heinemann.

Ihimaera, Witi. 2005. The Whale Rider. Oxford: Heinemann.

Knudsen, Eva Rask. 2004. The Circle and the Spiral: A Study of Australian Aboriginal and New Zealand Maori Literature. Amsterdam: Rodopi.

Knudsen, Eva Rask. 2011. "On Reading Grace's Potiki." CLCWeb: Comparative Literature and Culture 13(2): 1-10. Accessed June 15, 2017. http://docs.lib.purdue.edu/cgi/viewcontent.cgi?article=1745\&context=clcweb.

Murphy, Patrick D. 2015. Persuasive Aesthetic Ecocritical Praxis: Climate Change, Subsistence, and Questionable Futures. Maryland: Lexington Books.

Prentice, Chris. 2009. "From Visibility to Visuality: Patricia Grace's Baby No-Eyes and the Cultural Politics of Decolonization." Modern Fiction Studies 55(2): 321-348. Accessed June 15, 2017. https://muse.jhu.edu/article/269563.

Rangarajan, Swarnalatha. 2016. "Women Writing Nature in the Global South: New Forest Texts from Fractured Indian Forests." In Handbook of Ecocriticism and Cultural Ecology, edited by Hubert Zapf, 438-458. Berlin: De Gruyter.

Romaine, Suzanne. 2004. "Contested Visions of History in Aotearoa New Zealand Literature: Witi Ihimaera's The Matriarch." The Contemporary Pacific 16(1): 31-57. Accessed July 4, 2015. https://muse.jhu.edu/article/51215.

Sinclair, Karen P. 1992. "Maori Literature: Protest and Affirmation." Pacific Studies 15(4): 283-307. Accessed May 18, 2015.

https://search.proquest.com/openview/451e561ebd2bc5f682a6428fdfbe1911/1?pqorigsite $=$ gscholar $\&$ cbl $=1817199$.

Te Awekotuku, Ngahuia. 1996. "Maori: People and Culture." In Maori Art and Culture, edited by D. C. Starzecka, 114-46. New York: Columbia University Press.

Visser, Irene. 2010. "Words Against Death: Rites of Passage in Ana Castillo's So Far From God and Patricia Grace's Baby No-Eyes." In Rites of Passage in Postcolonial Women's Writing, edited by Pauline Dodgson-Katiyo and Gina Wisker, 283-300. Amsterdam: Rodopi.

Visser, Irene. 2012. "The Trauma of Goodness in Patricia Grace's Fiction." The Contemporary Pacific 24(2): 297-321. Accessed June 16, 2017. https://www.jstor.org/stable/23725604.

Walker, Ranginui. 1992. "Marae: A Place to Stand." In Te Ao Hurihuri: Aspects of Maoritanga, edited by Michael King, 15-27. Auckland: Reed.

Wepa, Dianne, and Jean Te Huia. 2006. "Cultural Safety and the Birth Culture of Maori." Social Work Review 18(2): 26-31. Accessed June 16, 2017. http://anzasw.nz/wpcontent/uploads/Te-Komako-Winter-2006-Articles-Wepa-and-Huia.pdf.

Williams, Mark. 2006. "The Long Maori Renaissance." In Other Renaissances: A New Approach to World Literature, edited by Brenda Deen Schildgen, 207-226. Gordonsville: Palgrave Macmillan.

Wilson, Janet. 2008. "Suffering and Survival: Body and Voice in Recent Maori Writing." In Bodies and Voices: The Force-Field of Representation and Discourse in Colonial and Postcolonial Studies, edited by Merete Falck Borch, Eva Rask Knudsen, Martin Leer and Bruce Clunies Ross, 267-281. Amsterdam: Rodopi. 
AUTHOR'S BIO: Ewa Kroplewska is a doctoral student at the Faculty of Languages at University of Gdańsk, working on her PhD dissertation devoted to the representations of postcolonial New Zealand. Her MA thesis was titled "Traditions of Storytelling: Salman Rushdie's Haroun and the Sea of Stories." She is interested in the applications of intertextuality and in the postcolonial writing, currently researching New Zealand literature.

E-MAIL: ewa.kroplewska(at)gmail.com 